\title{
Effects of rubber leaf litter vermicompost on earthworm population and yield of pineapple (Ananas comosus) in West Tripura, India
}

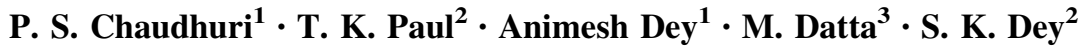

Received: 30 May 2015/Accepted: 1 March 2016/Published online: 15 March 2016

(c) The Author(s) 2016. This article is published with open access at Springerlink.com

\begin{abstract}
Purpose Rubber leaves are the abundant agro-waste and pineapple, the most economically important fruit crop in Tripura. So, in our present study, different amounts of rubber leaf vermicompost have been applied to the soils of pineapple plantation to determine their effects on earthworms - the soil ecosystem engineers, coupled with the vegetative growth and yield of pineapples.

Methods During 30 months of field trial (2010-2012) in ICAR regional station, Lembucherra, West Tripura, the control plot $\left(T_{0}\right)$ received no fertilizer, while experimental plots were fertilized with four different amounts of vermicompost viz. $T_{1}$ (5 tons $\mathrm{ha}^{-1}$ year $\left.^{-1}\right), T_{2}$ (10 tons $\mathrm{ha}^{-1}$ year $\left.^{-1}\right), T_{3}\left(20\right.$ tons $\mathrm{ha}^{-1}$ year $\left.^{-1}\right)$ and $T_{4}$ (30 tons $\mathrm{ha}^{-1}$ year $^{-1}$ ).

Results A significant $(p<0.05)$ but gradual increase in density (up to $T_{3}$ treatment) and biomass (up to $T_{4}$ treatment) of earthworms were recorded with the increasing amounts of vermicompost. During the second year, average length and width of leaves, number of leaves per plant, plant girth, fruit weight, fruit yield and fruiting percentage were highest in the $T_{3}$ plot compared to other treated plots and control.
\end{abstract}

P. S. Chaudhuri

priya_1956@rediffmail.com

1 Department of Zoology, Tripura University, Suryamaninagar 799022, Tripura, India

2 Regional Rubber Research Institute, Agartala 799006, Tripura, India

3 ICAR Research Complex for NEH Region, Lembucherra, Tripura, India
Conclusion The present study reveals that crop yield is very much related to the particular concentration of vermicompost, beyond the level of which production declines and increase in vegetative growth, fruit weight and fruiting percentage of pineapple are strongly linked with the soil $\mathrm{pH}$, av. $\mathrm{P}$, av. K, clay content and the earthworm density of soils.

Keywords Rubber leaf litter vermicompost - Earthworm population · Pineapple yield $\cdot$ Soil texture $\cdot$ Soil parameter . Principal component analysis

\section{Introduction}

One of the greatest challenges in today's agriculture is the need to adopt practices that protect environmental and ecological resources, minimize economic costs and promote social stability while sustaining high crop yields. It is widely believed that organic amendments to soil support higher earthworm populations by providing a nutrient rich substrate where they feed directly upon the organic matters or upon the microorganisms which colonize the organic materials. Despite the potential importance of earthworms in organic based agriculture, there have been few studies which have examined how application of manures like vermicompost affects earthworm populations. Werner and Dindal (1989) reported that manure amendments supported higher earthworm density and biomass than inorganic fertilizers after 5 years of Soybean-corn-legume rotations. Earlier Edwards and Lofty (1982) stated that in long-term continuous cereal production, earthworm abundance and biomass were greatest in plot receiving a combination of manure and inorganic fertilizer. 
Soil fertility depends on physical, chemical and biological soil attributes. Vermicompost is a nutrient rich, microbiologically active organic amendment which results from the interactions between earthworms and microorganisms in the breakdown of organic matter (Lazcano and Dominguez 2010). In fact, vermicomposts are finely divided peat-like materials with high porosity, aeration, drainage, water holding capacity and large surface area, providing strong capacity to hold and retain plant available nutrients such as nitrates, exchangeable phosphorus, soluble potassium, calcium, magnesium etc. (Edwards and Burrows 1988; Orozco et al. 1996; Chaudhuri et al. 2000). Compared to their parent materials, vermicomposts have less soluble salts, greater cation exchange capacity, increased total humic acid, available nutrients and biologically active substances such as plant growth regulators (Kale 2014). Based on physical, chemical and biological characteristics, vermicomposts have considerable potential for growing vegetables, fruit bedding plants, green house crops, etc. (Edwards et al. 2011). Interestingly, presence of certain plant hormones such as indole acetic acid adsorbed into the low-weight humic substances extracted from earthworm feces have recently been reported by Canellas et al. (2002) and Quaggiotti et al. (2004).

Literature is available on the impact of vermicompost on growth and productivity of different economically important cash crops in Indian subcontinent as well as from the other parts of the world (Bhattacharjee et al. 2001; Rakshit et al. 2008; Athani et al. 2009; Ansari and Sukhraj, 2010; Joshi and Vig 2010; Lazcano and Dominguez 2010; Theunissen et al. 2010; Gupta et al. 2011; Tharmaraj et al. 2011). Bhattacharjee et al. (2001) reported significant increase in both grain and straw yield in upland paddy in Tripura (India) coupled with improvement in soil aggregation, water use efficiency and nutrient uptake in vermicompost treated plots compared to the control and NPK treated plots.

In spite of available literature on impact of vermicompost on crop production, information is scanty on the effect of this organic manure on the activity of soil biota like earthworms (Whalen et al. 1998) that have most important role in the plant growth and crop production. In pineapple plantations of Tripura, fruits are grown in the hill slopes without any organic or inorganic soil additives. Here pineapple plantation harbors at least 11 earthworm species (Dey and Chaudhuri 2014). In spite of the fact that pineapple (Ananas comosus) is the most common and economically important cash fruit crop having high demand to the people of north-east India, there had been no scientific effort to increase its yield. Hence, application of vermicompost in the pineapple plantations of Tripura would be an important step for increasing earthworm activity and sustainable pineapple yields through organic farming (Behera et al. 2007; Karmegam and Daniel 2009) and restoration of degraded acidic soils as well (Butt 1999).

\section{Materials and methods}

\section{Experimental design}

The field was planted in December 2009, on a low fertility sandy clay loam red soil located at ICAR Regional Research Centre $\left(23^{\circ} 54^{\prime} \mathrm{N}-91^{\circ} 18^{\prime} \mathrm{E}\right.$, elevation $\left.52 \mathrm{~m}\right)$, Lembucherra, $20 \mathrm{~km}$ away from the city Agartala, West Tripura. Annual rainfall during the study period ranged from 1730 to $1972 \mathrm{~mm}$ during 2010-2012. Monthly rainfall ( $\mathrm{mm}$ ) and temperature (maximum and minimum) data in the study area, provided by Agro-metrological field unit (AMFU), Lembucherra (Tripura), are given in Fig. 1. The soil physico-chemical characteristics of the pineapple plantation plots prior to the experiment were: $\mathrm{pH} 3.89$, organic carbon $1.39 \%$, nitrogen $0.11 \%$, available Phosphorus (0.73 mg \%), Potassium (3.85 mg \%), electrical conductivity (EC) $48.75 \mu \mathrm{Mho}$ and $\mathrm{C} / \mathrm{N}$ ratio 12.37 .

Vermicompost (processed by Eisenia fetida from mixture of rubber leaf litter and cow dung wastes in 1:1 w/w) was collected from Adarini Vermicompost and Research Centre at Bhati Fatikchhera, West Tripura. The experiment was set up using a complete factorial design with 5 different amounts of vermicompost each having four replications. Vermicompost (VC) had organic carbon (OC) $9.36 \%$, nitrogen (N) $1.03 \%$, available phosphorus (av. P) $267.88 \mathrm{mg} \%$, available potassium (av. K) $348.0 \mathrm{mg} \%$, pH 6.20, electrical conductivity (EC) $5350 \mu \mathrm{Mho}$ and $\mathrm{C} / \mathrm{N}$ ratio 9.08. The amounts of vermicompost as applied in the experimental plots were $T_{0}$ (Control), $T_{1}$ (5 tons ha ${ }^{-1}$ year $\left.{ }^{-1}\right), T_{2}\left(10\right.$ tons $\mathrm{ha}^{-1}$ year $\left.^{-1}\right), T_{3}\left(20\right.$ tons ha ${ }^{-1}$ year $\left.^{-1}\right)$ and $T_{4}$ (30 tons ha ${ }^{-1}$ year $\left.^{-1}\right)$. Since the study site is located in high rainfall zone $(\sim 2000 \mathrm{~mm})$, pineapple sucker needs a considerable long period ( $\sim 18$ months) to bear fruit after planting and vermicompost release nutrients slowly, nutrient loss through leaching is a major issue to be considered. To minimize this problem, each of the above amounts of vermicompost was applied in three equal parts, three times a year, in each corresponding plot for consecutive 2 years. Thus each experimental plot received a total of six applications of vermicompost (in 4 monthly intervals) from January 2010 to February 2012. Vermicompost was applied on the surface soil, close to the rhizosphere zone of the plant. The control plot received neither vermicompost nor chemical fertilizer.

Each experimental plot was $25 \mathrm{~m}^{2}$ in size and composed of 5 rows (each row $5 \mathrm{~m}$ long) with 10 plants in each row. The spacing between the plants and in between the rows was 0.5 and $1.0 \mathrm{~m}$ respectively, resulting in a plant 
Fig. 1 Showing the monthly average rainfall $(\mathrm{mm})$ and atmospheric temperature $\left({ }^{\circ} \mathrm{C}\right)$ during the study period

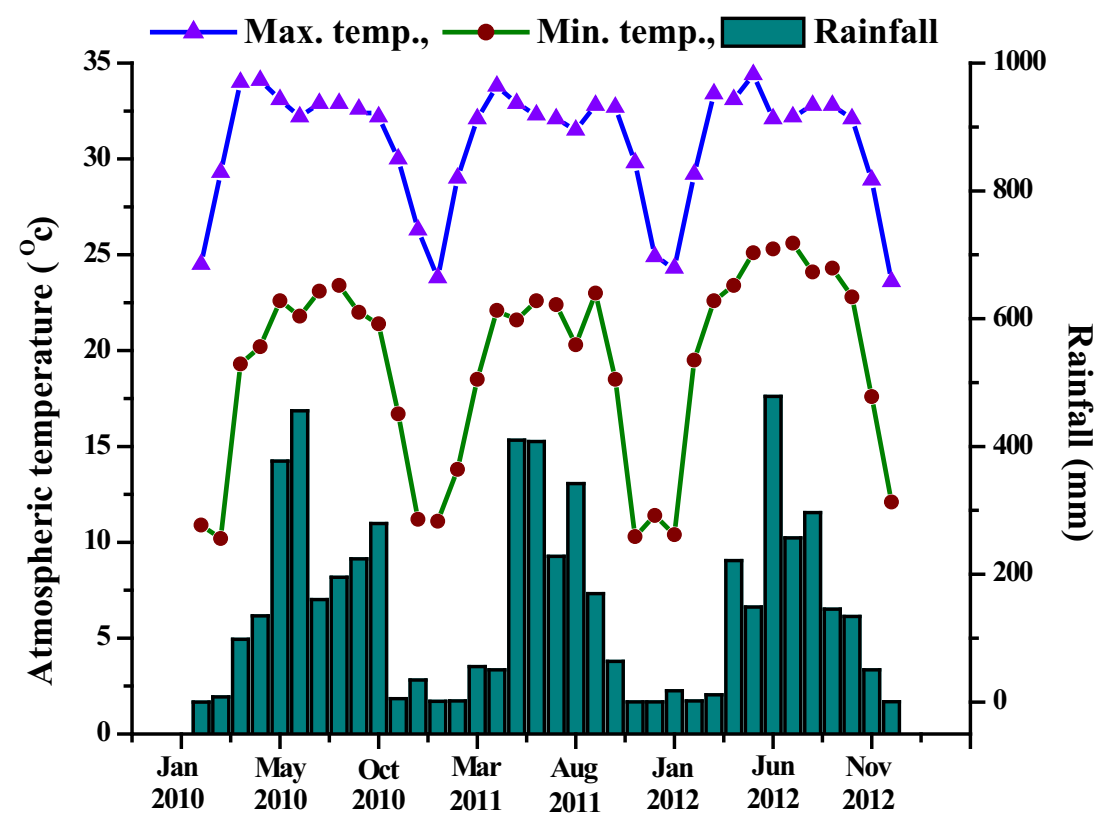

population of about 20,000 plants ha ${ }^{-1}$. Therefore, each individual plant of $T_{1}, T_{2}, T_{3}$ and $T_{4}$ treatment plots received $0.25,0.5,1.0$ and $1.5 \mathrm{~kg}_{\text {year }}{ }^{-1}$ of vermicompost respectively. Selected suckers of the Queen varieties of pineapples previously treated with recommended amounts of fungicides and pesticides were planted in the experimental plots.

\section{Analysis of plant growth and fruit yield}

Evaluation of pineapple plant growth, such as average number of leaves per plant, average leaf length, leaf width, plant girth etc. in each experimental plot was assessed during fruit harvesting summer season (in June). Randomly taken 20 pineapple plants and 10 mature leaves from each plant of a plot were considered for measuring of the number, length, width of leaves and plant girth.

The fruits were harvested during June 2011 and 2012 following 18 and 30 months of plantation. All the fruits from each plot were harvested, counted and weighed.

\section{Earthworm sampling}

To evaluate the effects of vermicompost on the community structure of earthworms in pineapple plantation plots, earthworms were collected by conventional digging and hand sorting method $(25 \mathrm{~cm} \times 25 \mathrm{~cm} \times 40 \mathrm{~cm}$ ) (Anderson and Ingram 1993; Dey and Chaudhuri 2014) between June 2011 to August 2012, during the activity periods (June-August) of earthworms. A total of 15 samples were taken (5 samples plot $^{-1}$ month $^{-1}$ ) from each plot during the sampling periods of a year. Thus a total of 30 samples were taken from each plot during 2 years of sampling. Therefore, overall 120 samples $\left(30\right.$ samples plot $^{-1} \times 4$ replica) were collected from a single treatment plot during the study period. Data were expressed in terms of density (ind. $\mathrm{m}^{-2}$ ) and biomass $\left(\mathrm{g} \mathrm{m}^{-2}\right)$.

\section{Soil analysis}

Composite soil samples (mixture of four replications) from control and vermicompost treated plots were collected during harvesting periods. The control and experimental sieved soil samples were subjected to analysis of different soil physico-chemical parameters. The $\mathrm{pH}$ was measured in 1:2.5 (w/v) aqueous solution (deionized water) (Jones 2001) using digital $\mathrm{pH}$ meter. Electrical conductivity (EC) was measured as described by Rhoades (1996). The organic carbon (OC) was determined by the partial-oxidation method (Walkley and Black 1934). Total soil nitrogen $(\mathrm{N})$ was measured by Micro Kjeldahl Method (Jackson 1975). Available phosphorus (P) was determined in $0.5 \mathrm{M}$ sodium bicarbonate extract using ascorbic acid colorimetric method (Kuo 1996) and available potassium (K) in $1.0 \mathrm{M}$ ammonium acetate extract by flame photometer (Jones 2001). Soil texture was measured by soil hydrometer (Daji 1996).

\section{Statistical analysis}

With the objective of evaluating significant differences among the different treatment plots for all soil parameters following the application of different amounts of vermicomposts, data were analyzed using one way ANOVA at 
Table 1 The variations in the soil physico-chemical properties due to the application of different amounts of vermicompost

\begin{tabular}{|c|c|c|c|c|c|c|c|}
\hline & \multicolumn{7}{|l|}{ Treatment plots } \\
\hline & $T_{0}$ & $T_{1}$ & $T_{2}$ & $T_{3}$ & $T_{4}$ & $F$ & $P$ \\
\hline Soil texture & $\begin{array}{l}\text { Sandy clay } \\
\text { loam }\end{array}$ & $\begin{array}{l}\text { Sandy clay } \\
\text { loam }\end{array}$ & Sandy clay loam & Clay loam & Sandy clay loam & - & - \\
\hline Soil pH (1: 2.5) & $3.89 \pm 0.04^{\mathrm{a}}$ & $4.06 \pm 0.09^{\mathrm{ac}}$ & $4.17 \pm 0.03^{\mathrm{ac}}$ & $4.67 \pm 0.31^{\mathrm{b}}$ & $4.46 \pm 0.07^{\mathrm{bc}}$ & 4.46 & $<0.05$ \\
\hline $\begin{array}{l}\text { Electrical conductivity } \\
(\mu \mathrm{Mho})\end{array}$ & $48.75 \pm 1.03^{\mathrm{a}}$ & $58.0 \pm 4.38^{\mathrm{ac}}$ & $66.5 \pm 2.87^{\mathrm{bc}}$ & $85.75 \pm 3.01^{\mathrm{d}}$ & $93.25 \pm 7.20^{\mathrm{d}}$ & 19.5 & $<0.05$ \\
\hline Organic carbon (\%) & $1.39 \pm 0.02^{\mathrm{a}}$ & $1.42 \pm 0.05^{\mathrm{ac}}$ & $1.47 \pm 0.02^{\mathrm{ac}}$ & $1.55 \pm 0.03^{b c}$ & $1.62 \pm 0.09^{\mathrm{b}}$ & 3.52 & $<0.05$ \\
\hline Total nitrogen (\%) & $0.11 \pm 0.003^{\mathrm{a}}$ & $0.14 \pm 0.003^{\mathrm{b}}$ & $0.16 \pm 0.005^{\mathrm{c}}$ & $0.17 \pm 0.003^{\mathrm{c}}$ & $0.22 \pm 0.004^{\mathrm{d}}$ & 138.26 & $<0.05$ \\
\hline $\mathrm{C}: \mathrm{N}$ ratio & $12.37 \pm 0.33^{\mathrm{a}}$ & $10.57 \pm 0.58^{b}$ & $8.77 \pm 0.30^{\mathrm{c}}$ & $8.98 \pm 0.09^{c}$ & $7.39 \pm 0.44^{\mathrm{d}}$ & 24.61 & $<0.05$ \\
\hline Available $P\left(\mathrm{~kg} \mathrm{ha}^{-1}\right)$ & $16.35 \pm 0.89^{\mathrm{a}}$ & $25.31 \pm 3.81^{\mathrm{a}}$ & $37.41 \pm 1.34^{\mathrm{ac}}$ & $64.51 \pm 20.83^{\mathrm{bc}}$ & $71.23 \pm 9.63^{\mathrm{b}}$ & 5.31 & $<0.05$ \\
\hline Available $K\left(\mathrm{~kg} \mathrm{ha}^{-1}\right)$ & $86.24 \pm 4.70^{\mathrm{a}}$ & $89.60 \pm 23.5^{\mathrm{a}}$ & $110.88 \pm 14.78^{\mathrm{ac}}$ & $176.96 \pm 14.56^{\mathrm{b}}$ & $153.44 \pm 21.95^{\mathrm{bc}}$ & 5.35 & $<0.05$ \\
\hline
\end{tabular}

Mean \pm SE, dissimilar letter indicate significant difference between data at $5 \%$ level of significance, $n=30$

$F$ F statistic value for ANOVA

$0.05 \%$ level of significance (Zar 2009). Where significant factors were evident, Tukey's post hoc test (Tukey 1953) was applied to examine which particular means were significantly different at $5 \%$ level of significance. A multivariate statistical technique, Principal component analysis (PCA) (Ammer et al. 2006; Salome et al. 2011) was performed to analyze the relationship of plant growth parameters, fruiting properties, earthworm density and biomass with the soil chemical properties. The original numbers of variables were summarized into a few principal components (PC) by means of PCA based on a correlation matrix (Moreira et al. 2003). Principal components (PC) with an Eigen value larger than 1 can be considered as factors with variances smaller than unity are no better than a single variable (Norusis 1992). Factor loadings are classified as strong, moderate and weak (Liu et al. 2003) corresponding to absolute loading values of $>0.75,0.75-0.50$ and $0.50-0.30$.

\section{Results}

\section{Effects of vermicompost on soil physical and chemical properties}

The application of vermicompost affected significantly the $\mathrm{pH}$ of the soils but the effects were depending on the strength of different amounts of vermicompost. Increasing amounts of vermicompost produced higher $\mathrm{pH}$ values of soils (Table 1). Highest pH value was observed in case of treatment plot $T_{3}\left(20\right.$ tons $\mathrm{ha}^{-1}$ year $\left.^{-1}\right)$. It is to be noted that soil $\mathrm{pH}$ in $T_{3}$ was significantly higher $(p<0.05)$ than that of $T_{1}$ and $T_{2}$ but at par with $T_{4}$. The electrical conductivity (EC) of the pineapple plantation soils gradually increased with the application of higher amounts of vermicompost (Table 1). Conductivity value varied significantly among the different treatment plots and was highest in case of $T_{4}$.

Application of vermicompost in different amounts influenced the soil texture i.e. percentage of sand, silt and clay contents of the soils of different treatment plots up to a great extent. A noticeable difference in soil separates was observed in $T_{3}$ plot (clay loam soil) compared to the control ( $T_{0}$, sandy clay loam). A $20 \%$ decrease in sand content and $10 \%$ and $30 \%$ increase in silt and clay contents respectively were noted in the $T_{3}$ among different treatment plots (Table 1). In contrast to $T_{0}, T_{1}, T_{2}$ and $T_{4}$ plots where the soil textures were sandy clay loam, in $T_{3}$ soil became clay loam due to combined effects of vermicompost and earthworm activity. There were dramatic rise in clay contents of soils in $T_{3}$ plot (Table 1).

The concentrations of soil organic carbon (OC) among the experimental plots differed significantly depending on the different amounts of vermicomposts applied. A gradual increase in the content of soil organic carbon with application of higher amounts of vermicompost in the experimental plot was observed (Table 1). A total of 2, 6, 12 and $16 \%$ increase of organic carbon were observed in case of $T_{1}, T_{2}, T_{3}, T_{4}$ plots respectively compared to the control. The highest value of organic carbon (1.62) was achieved in case of $T_{4}$ treatment plot (30 tons $\mathrm{ha}^{-1}$ year $^{-1}$ ). Increasing amounts of vermicompost also influenced the total nitrogen content of the soils positively and thus its gradual increasing trend was noted. Compared to control, the total soil nitrogen content was doubled in $T_{4}$ plot that received highest amount (30 tons $\mathrm{ha}^{-1}$ year $^{-1}$ ) of vermicompost during the field trial. The soil $\mathrm{C}: \mathrm{N}$ ratio, a measure of degradation and net mineralization of soil nutrients, showed a gradual decrease with increased amounts of vermicompost (Table 1). The amount of available soil $\mathrm{P}$ 
followed the trend same as those of the soil organic carbon and nitrogen. It was also increased gradually with the application of higher vermicompost amounts (Table 1). A highest of $335 \%$ and lowest of $55 \%$ increase in the amount of available $\mathrm{P}$ were observed in case of the soils of $T_{4}$ and $T_{1}$ plots respectively compared to control. Similarly, there were a highest of $105 \%$ and lowest of $4 \%$ increase in the amount of available $K$ in the soils of $T_{3}$ and $T_{1}$ plots (Table 1$)$. Highest silt $(27.5 \%)$ and clay $(32.5 \%)$ and lowest sand $(40 \%)$ in fact were recorded in $T_{3}$ plot (Table 1).

\section{Effects of vermicompost on species composition, densities and biomasses of earthworms}

A total of only four earthworm species viz. Pontoscolex corethrurus, Drawida assamensis, Drawida papillifer papillifer and Metaphire houlleti were collected from both the control and experimental plots while sampling during the post harvesting seasons of 2011 and 2012. No change in species composition of earthworms was recorded due to application of vermicompost for successive 2 years. On the basis of relative abundance, $P$. corethrurus was the most common species $(75 \%)$ followed by D. assamensis (20\%), M. houlleti (3\%) and D. papillifer papillifer $(2 \%)$. A significant $(p<0.05)$ but gradual increase in density (up to $T_{3}$ treatment) and biomass (up to $T_{4}$ treatment) of earthworms were noteworthy along with the increasing amounts of vermicompost (Table 2). Among the different treatment plots, highest earthworm density and biomass values were recorded in the $T_{3}$ and $T_{4}$ treatment plots respectively. Earthworm density varied from a lowest of 66 ind $\mathrm{m}^{-2}$ in $T_{1}$ to a highest of 128 ind $\mathrm{m}^{-2}$ in $T_{3}$ during first harvesting year and a lowest of 87 ind $\mathrm{m}^{-2}$ in $T_{1}$ to a highest 163 ind $\mathrm{m}^{-2}$ in $T_{3}$ during second harvesting year. On the other hand, earthworm biomass varied from a lowest of $13 \mathrm{~g} \mathrm{~m}^{-2}$ in $T_{1}$ to a highest of $34 \mathrm{~g} \mathrm{~m}^{-2}$ in $T_{4}$ plot during the first year of harvesting and a lowest of $17 \mathrm{~g} \mathrm{~m}^{-2}$ in $T_{1}$ plot to $35 \mathrm{~g} \mathrm{~m}^{-2}$ in $T_{4}$ plot during the second year of harvesting. Unlike earthworm biomass, where significant variations were observed in case of only $T_{2}$, density varied significantly $(p<0.05)$ in all the treatments except $T_{4}$ between the two harvesting seasons (Table 2).

\section{Analysis of plant parameters}

Atmospheric temperature and rainfall had no significant impact on plant parameters, as there were no noticeable variations of these factors during the study period (Fig. 1). Increasing amounts of vermicompost applied to the soils of experimental plots had significantly influenced the overall shoot growth parameters viz. number of leaves per plant, average leaf length, leaf width, plant girth, etc. Number of leaves per plant was not differed significantly in different vermicompost treatment plots compared to control during the first harvesting period. However, during the second harvesting period, difference was significant (Table 2). A gradual increase in number of leaves per plant up to $T_{3}$ followed by a sudden decrease in case of $T_{4}$ was noticeable. Highest number of leaves was observed in case of $T_{3}$ plot (Table 2). Unlike leaf number, the average leaf length and leaf width of pineapple plants of different treatment plots differed significantly compared to control during both the harvesting seasons (Table 2). However, the influence of vermicompost was clearly greater during the second year of fruit harvesting. In case of plant growth parameters like leaf length and leaf width, $T_{3}$ plot exhibited best results during both the harvesting seasons. Pineapple plant girth also followed the same trend and significantly increased with higher amounts of vermicompost but up to $T_{3}$ plot (20 tons $\mathrm{ha}^{-1}$ year $\left.^{-1}\right)$. All the parameters had significantly $(p<0.05)$ higher values during the second harvesting year compared to the first one (Table 2). In spite of receiving higher amount of vermicompost, ill response of all the above plant growth parameters in the $T_{4}$ compared to $T_{3}$ during both the harvesting seasons was noteworthy (Table 2).

\section{Effects of vermicompost on fruit yield}

Application of different amounts of vermicompost greatly influenced pineapple productivity. Although all the treatment plots had much better result compared to control during both the harvesting seasons, fruit yield (number of fruits $\mathrm{ha}^{-1}$ ) during the second year was significantly $(p<0.05)$ higher than that in the first year (Table 2). Although, the fruiting percentage and the yield increased in all the treatment plots compared to control, $T_{3}$ plot (20 tons $\mathrm{ha}^{-1}$ year ${ }^{-1}$ ) achieved the highest values of these two fruit parameters. A significant $(p<0.05)$ increase in fruiting percentage and fruit yields were observed in case of $T_{0}, T_{2}$ and $T_{3}$ during the second harvesting year compared to the first harvesting year (Table 2).

Gradual but significant increase in fruit weight (with and without crown) up to $T_{3}$ treatment followed by a decrease in $T_{4}$ was observed. However, pineapple weight (with and without crown) was recorded highest in case of $T_{3}$ treatment plot (Table 2). The weight of pineapples with crown for $T_{3}$ plot and without crown for $T_{2}, T_{3}$ and $T_{4}$ plots differed significantly $(p<0.05)$ between two harvesting periods (Table 2).

The results of the PCA of the soil physico-chemical, plant morphological and earthworm community parameters are presented in Fig. 2. Eigen values greater than 1 were 


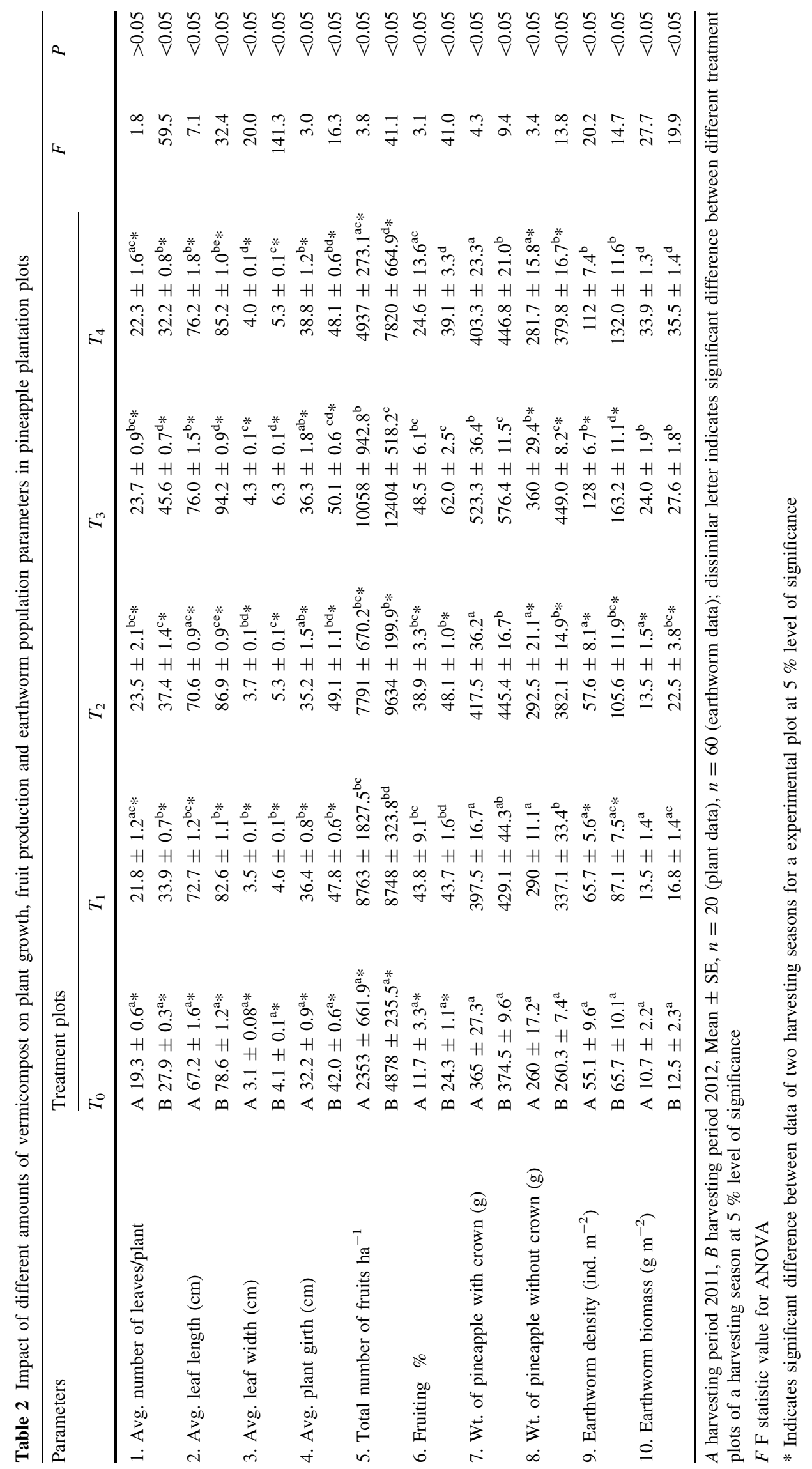




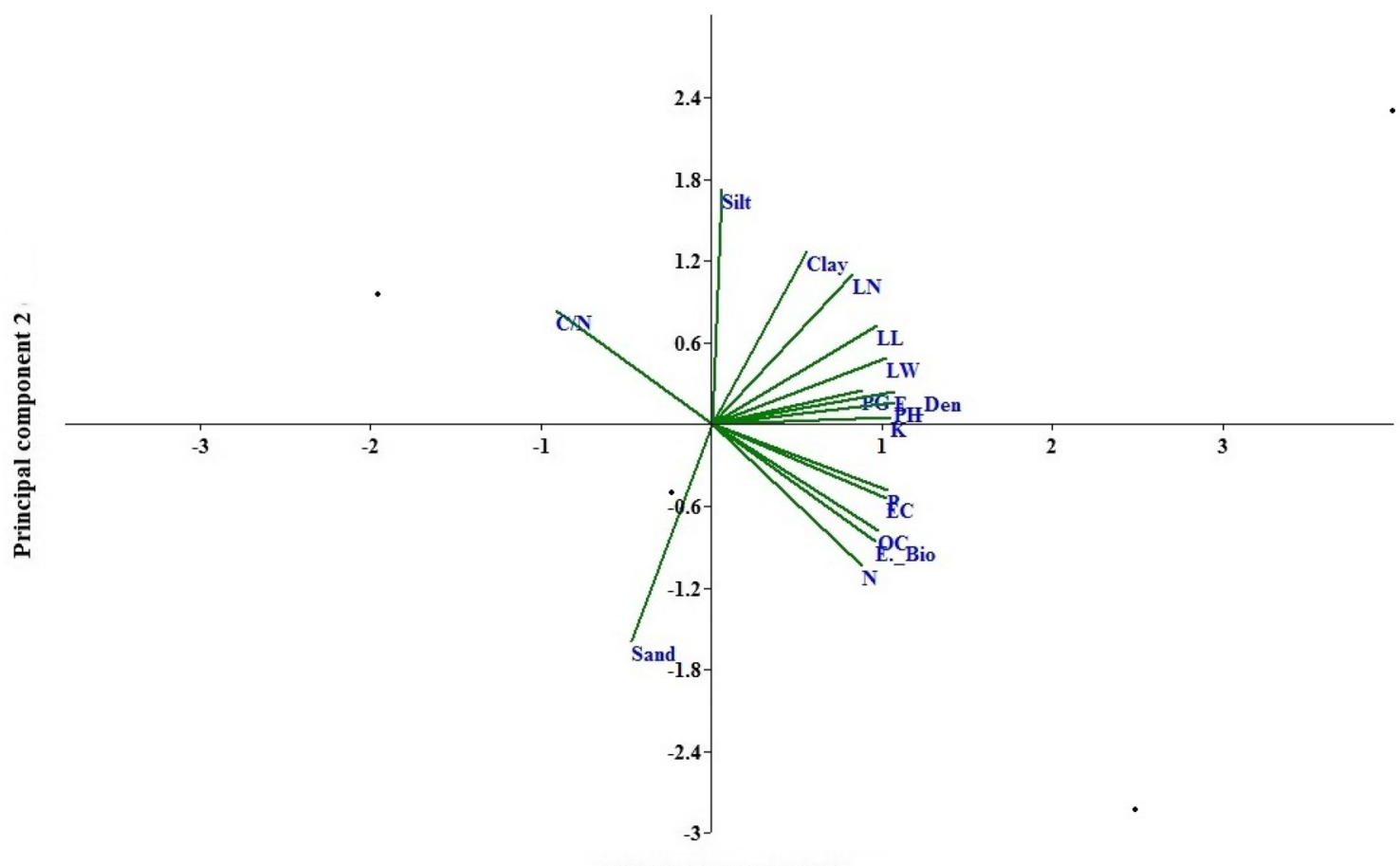

Principal component 1

Fig. 2 Principal component analysis (PCA) carried out with the plant growth, soil physico-chemical and earthworm community parameters ( $n=30) ; L N$ leaf number, $L L$ leaf length, $L W$ leaf width, $P G$ plant

taken as criterion for selection of the principal components required to explain the sources of variance in the data of pineapple yield (Ammer et al. 2006). Eigen value (7.50) showed that samples were mainly separated along with the first axis which explained $99 \%$ of the total variance (Fig. 2). Factor loading values are presented in Fig. 3. The principal component 1 has strong positive loadings $(>0.75)$ girth, $O C$ organic carbon, $N$ total nitrogen, $P$ available phosphorus, $K$ available potassium, $C / N$ C:N ratio, EDen earthworm density, EBio earthworm biomass

of plant morphological characters (leaf number, leaf length, leaf width and plant girth), soil $\mathrm{pH}$ and earthworm density, moderate positive loadings (0.50-0.75) of available $\mathrm{K}$ and $\mathrm{P}$ of soils, electrical conductivity, silt, clay percentage and negative loading of sand percentage, soil $\mathrm{C} / \mathrm{N}$ ratios. Soil parameters like total organic carbon and nitrogen showed weak positive loadings (Fig. 3).
Fig. 3 Showing the factor loadings of different plant growth, soil physico-chemical and earthworm community parameters for the principal component explaining the variances

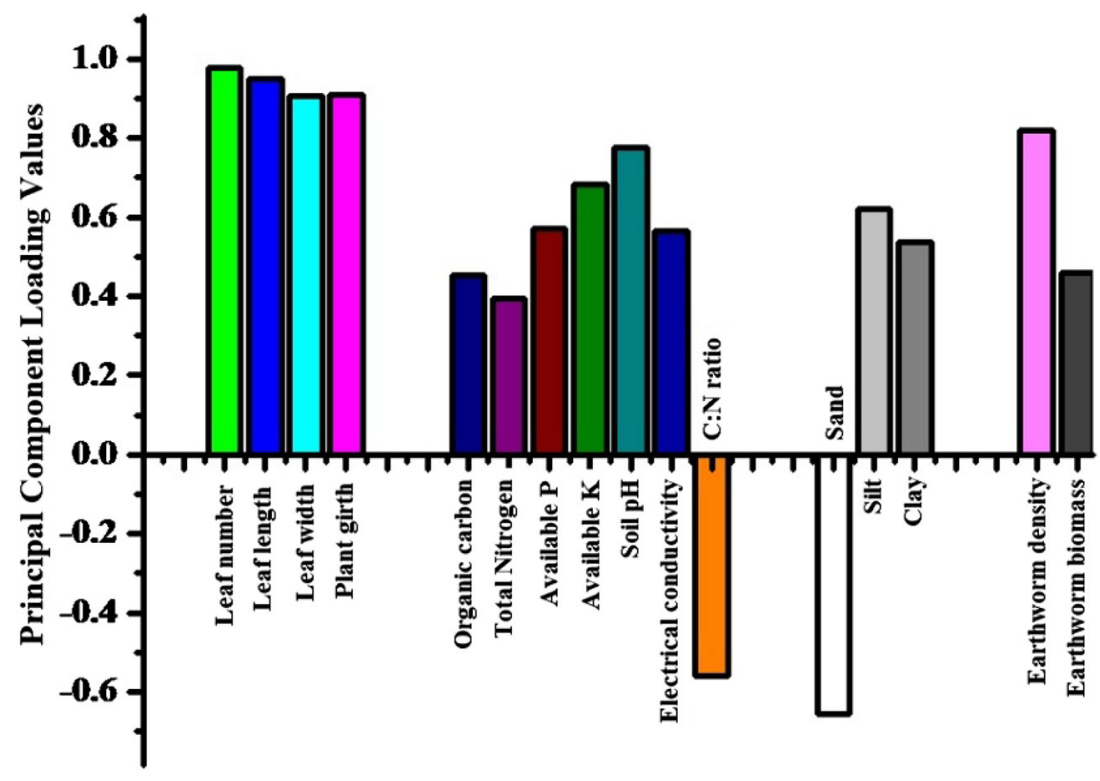




\section{Discussion}

The increase in density and biomass of earthworms coupled with growth and yields of pineapple grown in the vermicompost amended field soils could be attributed to several factors. Vermicompost reduces the loss of nutrients through leaching by improving the physicochemical and biological characteristics of the soils that favored better plant growth (Bhattacharjee et al. 2001). Gradual increase in soil $\mathrm{pH}$ with increasing amounts of vermicompost (up to 30 tons $\mathrm{ha}^{-1}$ year $^{-1}$ in $T_{4}$ ) during the present study corroborates with the findings of Gopinath et al. (2008), Suthar (2009) and Lazcano and Dominguez (2010). Gradual increase in soil electrical conductivity (thereby indicating increase in rate of mineralization) with increasing concentrations of vermicompost as found in the present study was also reported by Klock (1997) and Atiyeh et al. (2001). Increase in the electrical conductivity of field soils indicates increase in the rate of mineralization following application of vermicompost.

It is well known that vermicompost is a product of mesophilic biodegradation of organic materials through earthworm-microorganism interactions (Lazcano and Dominguez 2010). It usually contains a good proportion of organic carbon because unlike thermophilic composting reactions, in mesophilic vermicomposting process, least oxidative loss of organic carbon occurs (Sallaku et al. 2009; Theunissen et al. 2010). Hence, use of vermicompost as soil amendment helps in buildup of soil organic carbon (Ansari and Sukhraj 2010; Tharmaraj et al. 2011). The organic carbon in vermicompost releases the nutrients slowly and steadily into the soil and enables the plants to absorb the available nutrients (Lalitha et al. 2000).

That application of vermicompost as soil amendment leads to significant increase in the amount of total $\mathrm{N}$ (Bhattacharjee et al. 2001; Arancon et al. 2003; Ansari and Sukhraj 2010), available P and available K of soils (Ansari 2008; Joshi and Vig 2010; Lazcano and Dominguez 2010; Chanda et al. 2011) supports similar findings in our present experiment. Increase in the rates of nutrient uptake by plants with increase in production of cereals following application of vermicompost had earlier been reported by Kale et al. (1992) and Bhattacharjee et al. (2001).

Gradual decrease in $C: N$ ratios with increasing the amounts of vermicomposts applied to the pineapple plantation soils indicate higher mineralization rate resulting in the availability of significant quantity of micronutrients (Ansari and Sukhraj 2010).

Application of increasing amounts of vermicompost for successive 2 years (2010-2011) did not change the species composition of earthworms in pineapple plantation plots. Dominance of exotic earthworm $P$. corethrurus in the studied site is probably linked with anthropogenic effects in the form of intense agricultural activity in the ICAR regional research station (Chaudhuri et al. 2008). According to Huerta et al. (2006), earthworm communities tend to be mono-specific in agro-ecosystems and there is a trend towards exotic proliferation.

A gradual increase in earthworm population densities in the pineapple plantation plots with increasing the amounts of vermicompost and highest earthworm density in $T_{3}$ treatment plot are mainly associated with improvement of soil physical and chemical status. According to Lavelle et al. (1998) and Scheu (2003), in presence of earthworms, shoot biomasses increase which is evident in the present study. A significant increase in tea production over three consecutive years and a long-term improvement in soil quality following the recapitalization of soil in organic matter and promotion of intense earthworm activity were reported by Lavelle et al. (1998). Several authors reported positive influence of increasing soil $\mathrm{pH}$ (Edwards et al. 1995; Dlamini and Haynes 2004) and available soil K on earthworm population densities (Iordache and Borza 2010; Lalthanzara and Ramanujam 2010; Najar and Khan 2013). Increase in earthworm biomasses and densities in relation to total soil nitrogen, organic carbon and available soil phosphorus has also been reported by several authors (Mainoo et al. 2008; Iordache and Borza 2010; Chaudhuri and Dey 2013). In fact, addition of organic amendments increases earthworm population by conserving soil moisture as well as by providing food resource for earthworms (Werner and Dindal 1989). Nitrogen is often considered to be the critical factor limiting earthworms in many ecosystems (Curry 1998). Lower earthworm density in $T_{4}$ plot compared to $T_{3}$ might be linked with its higher levels of total soil nitrogen, very low $\mathrm{C}: \mathrm{N}$ ratio and soil $\mathrm{pH}$, which affect adversely the number of earthworms. Present result indicates that soils that support highest earthworm density $\left(T_{3}\right)$ may not be suitable for their highest biomass $\left(T_{4}\right)$. Interestingly, Chaudhuri and Bhattacharjee (2002) opined that a good biomass supporting medium may not be good medium for reproduction in earthworms. This differential biological response of earthworms is possibly linked with their differential nutritional and microhabitat characteristics of the soil habitat.

The difference in the density and activity of earthworms in the different treatment plots compared to control might be responsible for the alteration in the percentage of soil separates viz. sand, silt and clay. Dramatic rise in earthworm densities coupled with remarkable increase in clay contents and decrease in sand contents in $T_{3}$ plots compared to $T_{0}$ and other treatment plots are noticeable. Curry (1998) reported a positive relationship between clay content and earthworm abundance and a negative relationship between earthworm population and sand content of the soil. 
This alteration in the amount of soil separates is possibly due to selective feeding, physical grinding by gizzard and redistribution of soil particles by means of earthworms casting activities (Edwards and Bohlen 1996). Thus it appears that earthworms have an important role in determining soil textural classes. Panigrahi et al. (2014) advocated that development of sustainable agro-ecosystems amended with manure will have the capacity to support much greater earthworm population and biomass.

A remarkable increase in the size of the pineapple plants (leaf, shoot parts etc.) and yields of fruits were recorded following application of vermicompost. Present study indicated that for better growth of plants and yield of fruits optimum amount of vermicompost is required beyond the level of which no further growth and yield occur in spite of increasing the amounts of vermicompost. Thus $T_{3}$ plot fertilized with 20 tons ha $^{-1}$ year $^{-1}$ had significantly higher growth and yield of pineapple than in $T_{4}$ plots fertilized with 30 tons ha ${ }^{-1}$ year $^{-1}$.

Optimum plant growth is important for its greater final dry matter. In order to achieve this, optimum amounts of nutrients should be applied to the soil through inorganic or organic sources. In this study, growth of pineapple plantation is affected positively by the application of vermicompost that is an organic source of higher percentage of available nutrients necessary for plant growth (Nagavallemma et al. 2004). According to Edwards (1998) and Kale (2014), vermicompost plays a major role in improving growth and yield of different field crops including vegetables, flowers and fruits. An increase in the amount of soil nutrients, like nitrogen $(\mathrm{N})$, phosphorus $(\mathrm{P})$ and potassium $(\mathrm{K})$, due to the application of vermicompost (Ndakidemi and Semoka 2006; Kale 2014), is responsible for better growth and yield of pineapple. Bhattacharjee et al. (2001) reported significant increase in the yield of both grain and straw of upland paddy (TRC-87-251) coupled with water use efficiency and nutrient uptake compared to control and NPK treated plots in West Tripura. The physical improvement of soil structure and texture (percentage of sand, silt and clay) following application of vermicompost is also responsible for the better growth of pineapple plants. According to Arancon et al. (2011), high level of cytokinins, auxins and humic acid found in vermicompost besides the presence of plant available nutrients are some of the important factors for increasing height, leaf areas and shoot and root dry weights of plants.

Fruit yield of pineapple plants are associated with plant growth parameters viz. leaf number, length, width, girth plant $^{-1}$ etc. According to Hepton (2003) and Teixeira et al. (2011), it is necessary for plants to have satisfactory dry weight in order to produce adequate fruit size and overall yield. Field application of vermicompost showed strong relationship with pineapple plant growth and yield of fruits.
Among all the soil physico-chemical parameters, soil $\mathrm{pH}$, available phosphorus and potassium level are considered to be the most important factors in pineapple yield in the present study. In the present study, a positive and negative influence of clay and sand contents were observed in $T_{3}$ plot. According to Debnath et al. (2012), clay loam soils are generally favorable for pineapple growth and production. On the basis of Principal Component Analysis, it appears that increased vegetative growth, fruit weight and fruiting percentage are strongly linked with soil $\mathrm{pH}$, available $\mathrm{P}$, available $\mathrm{K}$, clay content and earthworm density of the soil, which are in agreement with the findings of Spironello et al. (2004), Tiwari (2005) and Ganeshamurthy et al. (2011).

Lower production of pineapple following the application of 30 tons ha $^{-1}$ year $^{-1}$ vermicompost $\left(T_{4}\right)$ than that of 20 tons $\mathrm{ha}^{-1}$ year $^{-1}$ in $T_{3}$ can be explained by the fact that optimum yield of crop was very much related to particular concentration of vermicompost, i.e. 20 tons $\mathrm{ha}^{-1}$ year $^{-1}$, beyond the level of which production declined and the reason is yet to be ascertained (Bhattacharjee et al. 2001).

In fine, application of vermicompost in the tropical soils of pineapple agro-ecosystem promotes plant growth and yield of fruits through increase in density and biomass of earthworms and physicochemical properties of soil.

Open Access This article is distributed under the terms of the Creative Commons Attribution 4.0 International License (http://crea tivecommons.org/licenses/by/4.0/), which permits unrestricted use, distribution, and reproduction in any medium, provided you give appropriate credit to the original author(s) and the source, provide a link to the Creative Commons license, and indicate if changes were made.

\section{References}

Ammer JA, Weber K, Abs C, Ammer C, Prietzel J (2006) Factors influencing the distribution and abundance of earthworm communities in pure and converted Scots pine stands. Appl Soil Ecol 33:10-21

Anderson JM, Ingram JSI (1993) Tropical soil biology and fertility: a handbook of methods, 2nd edn. CAB International, Wallingford

Ansari AA (2008) Effect of vermicompost and vermiwash on the productivity of Spinach (Spinacia oleracea) Onion (Allium cepa) and Potato (Solanum tuberosum). World J Agri Sci 4(5):554-557

Ansari AA, Sukhraj K (2010) Effect of vermiwash and vermicompost on soil parameters and productivity of okra (Abelmoschus esculentus) in Guyana. Afr J Agri Res 5(14):1794-1798

Arancon N, Lee S, Edwards C, Atiyeh R (2003) Effects of humic acids derived from cattle food and paper-waste vermicompost on the growth of greenhouse plants. Pedobiologia 47(5):741-744

Arancon NQ, Edwards CA, Webster KA, Buckerfield JC (2011) The potential of vermicomposts as plant growth media for Greenhouse crop production. In: Edwards CA, Arancon NQ, Sherman $\mathrm{R}$ (eds) Vermiculture technology. CRC Press, London, pp 103-128

Athani SI, Revanappa R, Dharmatti PR (2009) Effect of plant density on growth and yield in banana. Karna J Agri Sci 22:143-146 
Atiyeh RM, Edwards CA, Subler S, Metzger JD (2001) Pig manure vermicompost as a component of a horticultural bedding plant medium: effects on physicochemical properties and plant growth. Biores Tech 78(1):11-20

Behera UK, Sharma AR, Pandey HN (2007) Sustaining productivity of wheat-soybean cropping system through integrated nutrient management practices on the Vertisols of central India. Plant Soil 297:185-199

Bhattacharjee G, Chaudhuri PS, Datta M (2001) Response of paddy (var TRC-87-251) crop on amendment of the field with different levels of vermicompost. Asian J Micro Biotech Env Sci 3:191-196

Butt KR (1999) Inoculation of earthworms into reclaimed soils: the UK experience. Land Degra Dev 10(6):565-575

Canellas L, Olivares F, Okorokova-Facanha A, Facanha A (2002) Humic acid isolated from earthworm compost enhance root elongation lateral root emergence and plasma membrane $\mathrm{H}^{+}$. ATPase activity in maize root. Plant Physio 130:1951-1957

Chanda GK, Bhunia G, Chakraborty SK (2011) The effect of vermicompost and other fertilizers on cultivation of tomato plants. J Horti Fores 3(2):42-45

Chaudhuri PS, Bhattacharjee G (2002) Capacity of various experimental diets to support biomass and reproduction of Perionyx excavatus. Biores Tech 82:147-150

Chaudhuri PS, Dey A (2013) Earthworm communities in the pineapple (Ananus comosus) and mixed fruit plantations of West Tripura India. Proc Zoo Soc 66(2):105-118

Chaudhuri PS, Pal TK, Bhattacharjee G, Dey SK (2000) Chemical changes during vermicomposting (Perionyx excavatus) of kitchen waste. Tropical Ecol 41:107-110

Chaudhuri PS, Nath S, Paliwal R (2008) Earthworm population of rubber plantation (Hevea brasilensis) in Tripura India. Tropical Ecol 49(2):225-234

Curry JP (1998) Factors affecting earthworm abundance in soils. In: Edwards CA (ed) Earthworm Ecology. CRC Press LLC, Boca Raton, pp 26-39

Daji JA (1996) A text book of soil science. Media Promoters and Publishers Pvt. Ltd., Bombay

Debnath P, Dey P, Chanda A, Bhakta T (2012) A survey of pineapple and its medicinal value. Schol Acad J Pharm 1(1):24-29

Dey A, Chaudhuri PS (2014) Earthworm community structure of pineapple (Ananus comosus) plantations under monoculture and mixed culture in West Tripura India. Tropical Ecol 55(1):1-17

Dlamini TC, Haynes RJ (2004) Influence of agricultural land-use on the size and composition of earthworm communities in northern KwaZulu-Natal South Africa. Appl Soil Ecol 27:77-88

Edwards CA (1998) The use of earthworm in the breakdown and management of organic waste. Earthworm ecology. ACA Press LLC, Boca Raton, pp 327-354

Edwards CA, Bohlen PJ (1996) Biology and ecology of earthworms. Chapman and Hall, London

Edwards CA, Burrows I (1988) The potential of earthworm composts as plant growth media. In: Neuhauser CA (ed) Earthworms in environmental and waste management. SPB Academic Publisher, The Netherlands, pp 211-220

Edwards CA, Lofty JR (1982) The effects of direct drilling and minimal cultivation on earthworm populations. J Appl Ecol 19:723-734

Edwards CA, Bohlen PJ, Linden DR, Subler S (1995) Earthworms in agro-ecosystems. In: Hendrix PF (ed) Earthworm ecology and biogeography in North America. Lewis Publisher, Boka Raton, pp $185-213$

Edwards CA, Arancon NQ, Sherman R (2011) Vermiculture technology: earthworms organic wastes and environmental management. CRC Press, London
Ganeshamurthy AN, Sathisha GC, Patil P (2011) Potassium nutrition on yield and quality of fruit crops with special emphasis on banana and grapes. Karnat J Agri Sci 24(1):29-38

Gopinath KA, Supradip S, Mina BL, Pande H, Kundu S, Gupta HS (2008) Influence of organic amendments on growth, yield and quantities of wheat and soil properties during transition for organic production. Nutri Cycl Agro-ecos 82(1):51-60

Gupta AK, Ray B, Singh MP, Upadhyaya V, Singh CK (2011) Effect of fertilizers and vermicompost on growth yield and biochemical changes in Abelmoschus esculentus. Plant Arch 11(1):285-287

Hepton A (2003) Cultural System. In: Bartholomew DP, Paull RE, Rohrbach KG (eds) Pineapple: botany, production and uses. CABI Publication, Wallingford, pp 109-142

Huerta E, Fragoso C, Rodriguez-Olan J, Evia-Castallo I, MontejoMeneses E, Cruz-Mondragon M, Garcia-Hernandez R (2006) Presence of exotic and native earthworms in principal agro and natural systems in central and south-eastern Tobasco Mexico. Car J Sci 42:359-365

Iordache M, Borza I (2010) Relation between chemical indices of soil and earthworm abundance under chemical fertilization. Plant Soil Env 56:401-407

Jackson ML (1975) Soil chemical analysis. New Delhi, Practice Hall of India

Jones JB (2001) Laboratory guides for conducting soil tests and plant analysis. CRC Press, Boca Raton

Joshi R, Vig AP (2010) Effect of vermicompost on growth yield and quality of tomato (Lycopersicum esculentum L). Afr J Basic Appl Sci 2(3-4):117-123

Kale RD (2014) Earthworm biotechnology-source of sustainable agriculture. In: Chaudhuri PS, Singh SM (eds) Biology and ecology of tropical earthworms. Discovery Publishing House Pvt. Ltd., New Delhi, pp 185-194

Kale RD, Mallesh BC, Kubra B, Bagyaraj DJ (1992) Influence of vermicompost application on the available macronutrients and selected microbial populations in a paddy field. Soil Biol Biochem 24:1317-1320

Karmegam N, Daniel T (2009) Effect of application of vermicasts as layering media for an ornamental plant Codiaeum variegatum (L.) Bl. Dyn Soil Dyn Plant 3:100-104

Klock KA (1997) Growth of salt sensitive bedding plants in media amended with composted urban wastes. Composts Sci Utiliz $5: 55-59$

Kuo S (1996) Phosphorus. In: Sparks DL (ed) Methods of soil analysis Part III, chemical methods, SSSA Book Series No 5. SSSA, Madison, pp 869-912

Lalitha R, Fathima K, Ismail SA (2000) The impact of bio-pesticide and microbial fertilizers on productivity and growth of Abelmoschus esculentus. Vasundhara: The Earth 1-2:4-9

Lalthanzara H, Ramanujam SN (2010) Effect of fertilizer (NPK) on earthworm population in the agro-forestry system of Mizoram India. Sci Vision 10(4):159-167

Lavelle P, Barois I, Blanchart E, Brown G, Brussard L, Decaens T, Fragoso C, Jimenez JJ, Kajondo KK, Angeles Martinez MDL, Moreno A, Pashanasi B, Senapati BK, Villenave AC (1998) Earthworms as a resource in tropical agro-ecosystem. Nat Resour 34(1):26-41

Lazcano C, Dominguez J (2010) Effects of vermicompost as a potting amendment of two commercially-grown ornamental plant species. Spanish J Agri Res 8(4):1260-1270

Liu CW, Lin KH, Kuo YM (2003) Application of factor analysis in the assessment of ground water quality in a Blackfoot disease area in Taiwan. Sci Total Env 313:77-89

Mainoo NK, Whalen JK, Barrington S (2008) Earthworm abundance related to soil physico-chemical and microbial properties in Accra Ghana. Afr J Agri Res 3(3):186-194 
Moreira M, Blusztajn JS, Curtice J, Hart SR, Dick HJB, Kurz MD (2003) $\mathrm{He}$ and $\mathrm{Ne}$ isotopes in oceanic crust: implications for noble gas recycling in the mantle. Earth Planet Sci Lett 216(4):635-643

Nagavallemma KP, Wani SP, Lacroix S, Padmaja VV, Vineela C, Babu Rao M, Sahrawat KL (2004) Vermicomposting: recycling wastes into valuable organic fertilizer. Global Theme on Agroecosystems Report no 8. International Crops Research Institute for the Semi-Arid Tropics: Andhra Pradesh, India

Najar IA, Khan AB (2013) Factors affecting the distribution of earthworms in Kashmir Valley: a multivariate statistical approach. Proc Zoo Soc (Springer). doi:10.1007/s12595-013-0081-4

Ndakidemi PA, Semoka JMR (2006) Soil fertility survey in western Usambara Mountains northern Tanzania. Pedosphere 16(2):237-244

Norusis MJ (1992) SPSS PC Plus advanced statistics, Version 50 (Paperback)

Orozco SH, Cegarra J, Trujjillo L, Roig A (1996) Vermicomposting of coffee pulp using the earthworm Eisenia fetida: effects on $\mathrm{C}$ and $\mathrm{N}$ contents and the availability of nutrients. Biol Ferti Soil 22:162-166

Panigrahi PK, Lavelle P, Senapati BK (2014) Changes in macro-fauna and plant production in response to inoculation of endogeic earthworms and incorporation of organic matter in tea garden ecosystem of South India. In: Chaudhuri PS, Singh SM (eds) Biology and ecology of tropical earthworms. Discovery Publishing House Pvt. Ltd., New Delhi, pp 223-229

Quaggiotti S, Ruperti B, Pizzeghello D, Francioso O, Tugnoli V, Nardi S (2004) Effect of low molecular size humic substances on nitrate uptake and expression of genes involved in nitrate transport in maize. J Exp Bot 55:803-813

Rakshit S, Matocha CJ, Coyne MS (2008) Nitrite reduction by siderite. Soil Sci Soc Am J 72(4):1070-1077

Rhoades JD (1996) Salinity: Electrical Conductivity and Total Dissolved Solids. In: Sparks DL (ed) Methods of soil analysis Part III, chemical methods SSSA Book Series No 5. SSSA, Madison, pp 417-435

Sallaku G, Babaj I, Kaciu S, Balliu A (2009) The influence of vermicompost on plant growth characteristics of cucumber (Cucumis sativus L.) seedlings under saline conditions. J Food Agri Env 7(3-4):869-872
Salome C, Guenat C, Bullinger-Weber G, Gobata JM, Bayon RCL (2011) Earthworm communities in alluvial forests; influence of altitude vegetation stages and soil parameters. Pedobiologia 54S:S89-S98

Scheu S (2003) Effects of earthworms on plan growth: patterns and perspectives. Pedobiologia 47:846-856

Spironello A, Quaggio JA, Teixeira LAJ, Furlani PR, Sigrist JMM (2004) Pineapple yield and fruit quality affected by NPK fertilization in a tropical soil. Rev Barasi de Fruti Jaboti 26(1):155-159

Suthar S (2009) Impact of vermicompost and composted farmyard manure on growth and yield of garlic (Allium stivum L.) field crop. Int J Plant Prod 3(1):27-38

Teixeira LAJ, Quaggio JA, Cantarella H, Mellis EV (2011) Potassium fertilization for pineapple: effects on plant growth and fruit yield. Rev Bras De Fruti Jabot 33(2):618-626

Tharmaraj K, Ganesh P, Kolanjinathan K, Suresh KR, Anandan A (2011) Influence of vermicompost and vermiwash on physico chemical properties of rice cultivated soil. Curr Bot 2(3):18-21

Theunissen J, Ndakidemi PA, Laubscher CP (2010) Potential of vermicompost produced from plant waste on the growth and nutrient status in vegetable production. Int $J$ Phy Sci 5(13):1964-1973

Tiwari NK (2005) Diagnosing potassium deficiency and maximizing fruit crop productivity. Bett Crops 89(4):29-31

Tukey JW (1953) The problem of multiple comparisons. In: Braun HI (ed) The collected works of John W. Tukey VIII. Multiple Comparisons. Chapman and Hall, New York, pp 1948-1983

Walkley A, Black IA (1934) Determination of organic carbon in soil. Soil Sci 37:29-38

Werner MR, Dindal DL (1989) Earthworm community dynamics in conventional and low-input agro-ecosystems. Rev Ecol Biol Soil 26:427-437

Whalen JK, Parmelee RW, Edwards CA (1998) Population dynamics of earthworm communities in corn agro-ecosystems receiving organic or inorganic fertilizer amendments. Biol Ferti Soil 27:400-407

Zar JH (2009) Biostatistical analysis, 5th edn. Prentice Hall, Englewood Cliffs 